\title{
The Effect of Siputspin Learning Media on Symmetry Material in Grade V Elementary School
}

\author{
Maghfiroh Izza Maulani*, Ashma Nur Hanifah Heninda Putri, Faddliyah, \\ Novia Nur Afifah, Aji Pangestu \\ Mathematics Education Department, Faculty of Math and Science, Universitas Negeri Yogyakarta, \\ Jl. Colombo No.1, Karang Malang, Caturtunggal, Depok, Sleman, Daerah Istimewa Yogyakarta 55281, Indonesia. Tel: +62-274-586168 \\ Email*: maghfirohizza9@gmail.com
}

\begin{abstract}
Mathematics is a subject that is clearly understood. Likewise, mathematical material seems difficult, one of which is about rotary symmetry. This material is difficult because it requires extra understanding, logic and imagination. For this reason, a siputspin learning media was made to facilitate students. This research was appointed because the author wants to know how much influence the media of siputspin learning makes it easier for fifth grade elementary school students to understand the material of rotating symmetry. The author uses an experimental method whose data source is obtained consisting of interviews, observations, questionnaires, and book reviews. The subjects of this study consisted of several fifth grade elementary school students in Yogyakarta. Determination of the subject is done by random sampling. Data collection techniques are done by interviewing and filling in questionnaires with students and direct observation in class. The data of this study were analyzed descriptively quantitative and qualitative. The results showed that the siputspin learning media can make it easier for students to understand rotational symmetry material. Nevertheless, there are still a number of things that need to be improved from the siputspin learning media to be more effectively applied.
\end{abstract}

Keywords: Siputspin, Learning media, the effect

\section{INTRODUCTION}

Education in Indonesia starts from elementary school, junior high school, high school to college. There are various lessons that must be learned by students. One of them is mathematics. Elementary School (SD) students are generally at the stage of concrete thinking that is marked by logical reasoning about things that can be found in the real world. This mathematics subject needs to be given to students starting from elementary school to equip students with the ability to think logically, analytically, systematically, critically and creatively and have the ability to cooperate. According to Heruman (2007) concepts in elementary mathematics curriculum can be divided into three large groups, namely the planting of basic concepts (concept planting), understanding of concepts, and coaching skills. The ultimate goal of learning mathematics in elementary school is so that students are skilled in everyday life.

In Indonesia, curriculum 13 has been launched with the aim of improving education in Indonesia. In reality, most Indonesian education still uses conventional or teacher-centered learning. Thus, learning seems boring. Especially for learning mathematics that is already considered to be a frightening specter. Mathematics is one of the subjects that is quite difficult for students because it requires high thinking to understand the abstract mathematical object. According to Van Hiele (in Van De Walle, 2006: 151), there are three main elements in the teaching of Geometry, namely time, teaching material, and teaching methods applied. If all three elements are passed in an integrated manner it will be able to improve students' thinking abilities to the higher stages of thinking. One of the materials that is difficult for Elementary School students is rotating symmetry material on a flat figure.

Overcoming boring and uninteresting learning is to use learning media. Sudjana \& Rivai (2010) revealed that the game media can enhance the learning process of students which in the end is expected to enhance the learning outcomes they achieve. Learning media is expected that students can more easily learn and understand a subject matter, the media are also expected to increase student interest in learning where learning takes place will be more interesting than conventional learning in general (Fanani etc, 2017). Learners become interested in learning that uses learning media.

Siputspin is a learning media for play symmetry material. Play symmetry material itself is in grade $\mathrm{V}$ elementary school. Students are still confused in determining the amount of rotational symmetry on a flat figure. With the presence of SiputSpin, students are able to determine the amount of rotational symmetry and can present a learning atmosphere that is not boring and interesting. Enabling learning will achieve its objectives. Thus, the selection of appropriate methods and approaches as well as the use of effective and efficient learning media becomes a necessity that needs to be done by the teacher. One of the innovative learning designs is to stimulate the active role of students in mathematics learning (Suhada, 2018). 


\section{MATERIALS AND METHODS}

\section{Study area}

This research was conducted in fifth grade students of elementary schools in Yogyakarta. Especially in the matter of rotational symmetry.

\section{Procedures}

The procedure of this research can be seen from the following chart:

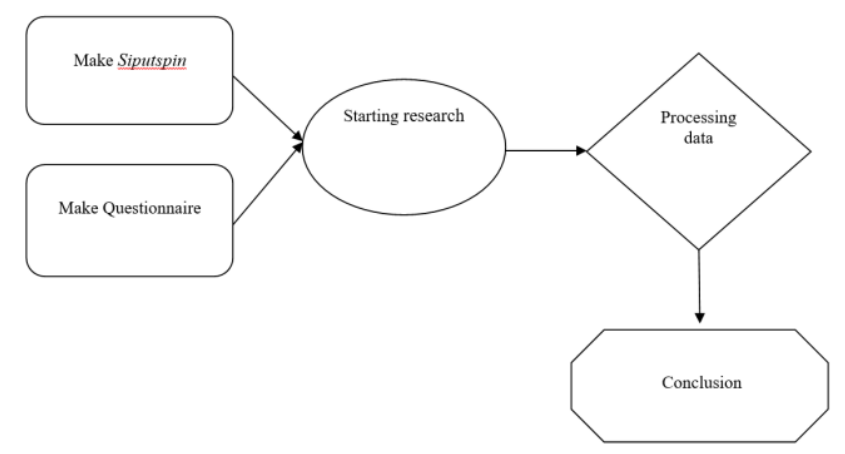

Figure 1. Procedures.

Make a Siputspin is easy. The materials are also easily available in the surrounding environment. The Materials that we need are,

1. Compass

2. Pencils or pens

3. Ruler

4. A small straw

5. Scissors

6. Gun glue

7. Origami or colored paper

8. Paper hole punch

9. Cardboard

How to make Siputspin is quite easy, namely:

1. Draw a flat figure pattern (circle, pentagon, square, triangle, and or desired image) on cardboard and origami paper with a ruler and a term, then scissors according to the drawing made.

2. Next, draw 2 small circles on cardboard and origami paper with the help of the term provided, scissors according to the drawing. On both circles the protractor is painted a full circle. The function of this circle is, as a spinner shaft to rotate at once to express the magnitude of changes in the object's rotation in degrees.

3. Stick the entire cardboard that has been scissors with similar origami paper.

4. Make a hole in the middle of the flat shape pattern that has been made with a paper hole puncher to insert the shaft to be made later.

5. Next attach 1 circle that has been cut beforehand as a spinner spinning shaft with a small straw. Put in a flat area pattern that has been given a hole. Then, cut the straw so it doesn't get too long and reattach it with 1 remaining circle attached with origami paper that has been cut beforehand.

6. Siputspin from the cardboard base material is finished made and ready to play.

To make effective use of Siputspin, Siputspin can be made all in one, by combining various shapes of flat shapes that have been made in one spinner.



Of the several students in a tutoring that we studied, $71 \%$ of them understood and were interested in the symmetry material of play. $54 \%$ of respondents have a high interest in learning. For this reason, it can be concluded that the Siputspin. learning media influences students' interest in rotational symmetry material. 


\section{CONCLUSION}

From the results of the questionnaire, we know that students' interest in mathematics is not so high. Most of them like reading math books, but not to do math problems. For students' interest in learning mathematics is sufficient. Because from the writer's research, students sometimes learn or not. Some like to work on problems, but still need help. Students often feel bored in class, so busy playing or chatting with friends. For elementary school scale, students are still very dependent on the teacher. Students pay attention when the teacher explains, but for independent learning students cannot.

Most students prefer to play while studying. Students are more interested in learning media than monotonous reading books or working on problems. Even learning media does not reduce their understanding of the material. Even students who have never received rotating symmetry material understand that they are using Siputspin. given at the end of the discussion.

\section{ACKNOWLEDGEMENTS}

Our gratitude goes to God is Allah because for his gift we were able to complete this paper. In addition to
Timoho Study Guidance provided an opportunity to complete this research. So that it is expected to be beneficial to readers and to all parties who we cannot mention one by one.

\section{REFERENCES}

Heruman, (2007). Model Pembelajaran Matematika di Sekolah Dasar. Bandung: Rosdakarya.

Sudjana \& Rivai. (2010). Media pengajaran. Bandung: Sinar Baru Algensindo

Suhada. 2018. Peningkatan Motivasi dan Hasil Belajar Matematika Siswa Kelas VI SD melalui Alat Peraga Bangun Ruang. Makalah Disajikan pada Lomba dan Seminar Matematika XXVI: Harmonisasi Matematika dalam Membangun Bangsa. Jurusan Matematika FMIPA Universitas Negeri Yogyakarta, Februari 2018.

R. M. Fanani, Dafik and Arif Fatahillah, Pengembangan Media Pembelajaran Interaktif Online Menggunakan Edmodo Berbantuan Software Geogebra pada Materi Sistem Persamaan Linier Dua Variabel, Kadikma, vol. VIII, no. 2, pp. 78-85, 2017.

Van De Wall, John A. 2006. Matematika Sekolah Dasar dan Menengah Pengembangan Pengajaran. Jakarta: Erlangga. 
THIS PAGE INTENTIONALLY LEFT BLANK 